\title{
MARGINS OF ARCHITECTURE ${ }^{1}$
}

\section{A B S T R A C T}

Starting from the example of the particularly ugly Palazzo Nuovo in Turin, this paper aims at providing, by way of comparison between architecture and visual arts, ten interpretations (conceptuality, auraticity, supplementarity, irresponsibility, parergonality, authoriality, subalternity, documentality, pyramidality, reality), which describe the characteristics of contemporary architecture as well as indicating certain limits and rules that architecture must necessarily come to terms with. 
Allow me to begin with a cry from the heart, and reveal to you a sore subject in my life. In Turin, I teach at the Palazzo Nuovo, the seat of the Humanities Department. It is a clamorous confrontation between philosophy and architecture. Perhaps even a caveat. The main architect of the Palazzo Nuovo, Gino Levi-Montalcini (as we learn in a book by Paolo Mauro Sudano entitled Maestri difficili. Temi d'architettura torinese e il parallelo di una scuola di filosofia, or, "Difficult Masters. Topics of Turinese Architecture and the Parallel of a School of Philosophy"), turned to eighteenth-century thought such as Kant, Hegel and Croce - and to Existentialism. Despite his first-rate intentions and excellent readings, for me, the outcome has been the following: for 38 years, albeit with sometimes long and wholesome interruptions (as the building is full of asbestos), I have been dealing both in my work and studies, with an architectural monster. I first set foot in it as a student in 1974, finding it horrendous even then. It has continued to worsen, being torrid in the summertime and frigid in the winter, as ugly as the town hall in Kabul, full of draughts and whistles at the first breath of wind just as in Dracula's castle, without adequate elevators, or even adequate space for libraries. And, thanks to continuous remodelling, patch-ups and reparations, it has proven to be more costly than the Taj Mahal. All in all, it is a catastrophe, an abyss that breeds other abysses, because in the face of a deteriorated structure even respect and pity lack, and if generations of graphomaniacs inscribed their names on the walls of the Castel del Monte, we can only imagine what destiny awaits this miserable product of the Sixties.

In spite of this, a few days ago I happened to have a dinner-table conversation with a Turinese architect and academic who was very interested in philosophy, and who was determined to undertake a particularly difficult exercise which consisted in convincing me that the Palazzo Nuovo was beautiful. Or, more precisely, that it was beautiful at the time it was built. That we no longer have the criteria to appreciate it, but that, nonetheless, we must not assert our current haughtiness towards the achievements of our ancestors. I retorted that the Palazzo Nuovo must have reached its aesthetic acme for a truly brief time, possibly only in its earliest days (in what we call the "beauty of a young donkey"), since already in 1974, three years after its inauguration, I found it horrendous. And that contrarily, the Pyramids, with their immense antiquity, seem to have challenged time also from the point of view of beauty, just as the bust of Nefertitis. He objected that the pyramids were ugly (I reckon he meant "ugly in the absolute", ugly from the time of Keopes until the exact moment in which the architect and academic told me that they were ugly). 
I counter-objected that even so, at least no one was forcing him to live in a Pyramid, while I, as many other professors and students, have been afflicted by that place for over forty years. I have suffered its functional inadequacies and its ungainliness, slovenliness, aesthetic ill-formations, not to mention the damage from asbestos that cannot be attributed to the philosophising architect. By and large, I, as well as thousands of other human beings personally paid for the incompetence or the negligence of one man - or rather a group of men, as Felice Bardelli, Sergio Hutter and Domenico Morelli had also worked on the project. I proposed to the architect that we switch buildings. Since he liked the Palazzo Nuovo so much, he could come to my office, and give me his, in a splendid palazzo built in the seventeenth century by Carlo and Amedeo di Castellamonte that was beautiful then just as it is now, and was most likely also beautiful in the time in between. The architect and academic did not show enough respect for philosophy, but we later wrote each other and he will come visit me soon, although for a limited time, to discuss the topics we only alluded to over dinner.

I would like to lay my cards on the table. Nothing authorises me to speak of what I do not know - that is, of architecture - if not my particularly acute architectural discontent towards the Palazzo Nuovo. It is, in its own way, a perfect symbol embodying architectonic infelicity much more and much better than the Spielberg in Brno embodied Habsburgian despotism. The Spielberg is beautiful as it straddles the line between a castle and a monastery. It is certainly not as beautiful as the Villa Tugendhat, also in Brno, but infinitely more beautiful than the Palazzo Nuovo. Is it not inhumane that thousands of students and professors have been subjected to a residence in a place that is more afflictive than the harsh prison of the Habsburgs? And, since I refuse to believe that Gino Levi-Montalcini and his three colleagues were faced with the same reasonably revengeful will that Kaiser Franz Joseph I fostered for Silvio Pellico and Piero Maroncelli (who, after all, wanted to take away the Lombardo-Veneto kingdom from him), it comes down to asking ourselves why. Why? I would like to answer this question not with facts (it seems to me that the Palazzo Nuovo is more than adequate representation of that category) but through ten interpretations. As we will see, the majority of these indicate certain limits and rules that a architecture must necessarily come to terms with.

\section{CONCEPTUALITY}

The initial interpretation, perhaps a bit surprising and apparently off-topic, has to do with what I will call "conceptuality". Architecture, like visual arts and 
more than visual arts (because it did not have a choice), also underwent the conceptual turning point of the last century: namely the idea that what counts, in art, is not the work but the concept that generated it or that it manifests. If in a museum we resign ourselves to seeing the simple memoranda of the artists' ideas, it is truly sad - sinister, even - to live in the concept of a stranger, or perhaps, as in the case of the Palazzo Nuovo, of four strangers: we want to live in a real house, study and teach in a real university, etc. Unfortunately, though, this was not the case.

In his piece in the opening remarks for the conference Architecture and Realism, Renato Capozzi rightly notes that in (architectural) deconstruction there is a gusto for novelty at all costs. He adds, and I would like to underscore this, that the advent of such an intrinsically problematic notion as "architectural deconstruction" (which, let us not forget, also appeared to Derrida) was delightfully welcomed. Why? It is clear, because it sounded like a provocation, an ironical remark or something to attract such attention. After all, there was also weak architecture, which recalls the houses of the dumbest two of the three little pigs. First, there was Heideggerian architecture, and before that there were many others. And covering them all, in terms of results, there were vast umbrella-words that counted as universal justifications: "Modern", "Postmodern" etc. (In particular, we should reflect on the intimately exculpatory meaning, be it even in its resignation, that is deposited in the phrase "modern architecture").

There are two sides to all of this. On the one hand, it is obvious and dutiful that an architect be part of the culture of his era, because he is a man of culture. On the other hand, however, an architect's recourse to theory is oftentimes thought to be similar to that of an artist, who stakes his all on the conceptual, considering the actual work to be a trifling detail.

\section{AURATICITY}

Let us turn to my second interpretation, which concerns a phenomenon that I propose we call "auraticity". As I suggested in the previous interpretation, the matters related to architecture are better understood when paralleled to those of the visual arts. This assertion may appear surprising, or perhaps obvious, but I believe it to be true. It is what Loos wrote: "a house (architecture) must be pleasing to all. Unlike a work of art which does not need to be pleasing to anyone. Not a house. A work of art is brought into the world without there being a need for it. A house instead satisfies a need (purpose). A work of art is 
not responsible towards anyone, a house towards everyone". He wrote this in Parole nel vuoto, or "Words into Nothingness", an extraordinarily prophetic title. Certainly, between visual arts and architecture there are reciprocal actions and certain repercussions, a bit like when the pressure of the Huns on the Germanics determined the invasion of the Roman Empire. The prevalence of conceptuality derives from the visual arts and, going back in time, from Romanticism.

I must, then, emphasise a particularly significant consequence of conceptualisation. Contrary to what is normally said in the wake of Benjamin, twentieth-century art is not characterised by a "loss of the aura", caused by the giving out of its uniqueness, but, on the contrary, by an unprecedented hyper-auratisation, brought about by the hyper-conceptual character of art. Consequently, as suggested by the analysis of Alessandro Dal Lago and Serena Giordano, Mercanti d'aura. Logiche dell'arte contemporanea ["Merchants of Aura. Logics of Contemporary Art"] $]^{3}$, more than with the disappearance of aura, we are dealing with its systematic regeneration, at the hands of the art market. This, then, is the premise of every discourse on contemporary art, where it is more or less easily assumed that the art world is the generator of art works, acting as both the place of production and of conferment of aura. And that aura may legitimately take the place of beauty in the role of "aesthetic identifier" of the art work, which at this point (in order to distinguish it from traditional works of art, which were still active in the system of the beaux arts) I am proposing we call work of aura. Galleries and museums are full of works of aura, and, on closer inspection, the only way to make the Palazzo Nuovo acceptable would be to exhibit it as a ready-made in a museum for giants.

\section{SUPPLEMENTARITY}

The third interpretation concerns what I propose we call "supplementarity". In a work of aura the unfortunate correlate of auraticity is inaestheticity: the hyper-romantic idea (it was Rosenkranz, a Hegelian, who in 1853 published the momentous book, The Aesthetics of Ugliness) that beauty is, above all, a hindrance for a work of art. Nevertheless, since we cannot do without beauty, if not grudgingly or by error (I am convinced that Levi-Montalicini, unlike Duchamp, considered the Palazzo Nuovo to be beautiful in some way), after the great refusal of the visual arts, other branches, such as design or even architecture (not to mention the infinite field of the pop world) must carry out a supplementary function, generating figures that were once unimaginable, such as fashion victims, design maniacs and compulsive show visitors. 
Or giving life to strange common-law couples - this is the most immediate of the repercussions of works of aura on architecture - such as that between hyper-architectural museums and the works housed within them. Museums, in general, are all different, with the exception of their name, which is always a variation of Moma, or even Moba (the genius Museum of Bad Arts in Boston) and the pending Mumia (the possible new name for the Egyptian Museum in Turin, revised as a museum of Body art). The housed works, however, are all the same, all uniformly transgressive; that is to say, they are all unanimous in not searching for beauty, because if they were to do so they would be relegated, instead of a museum, to a more modest space - a design shop, for instance.

This is, therefore, a third repercussion of the work of aura on the environment: the aesthetic indifference of works (which, however, are exonerated through useful ends) has at times generated an aesthetic hyphen missing in design and in architecture, as demonstrated by the systematic concealment of buttons (reputed to be unaesthetic) on printers and photocopiers, or the concealment of switches and sockets by Siza in the restoration of the Madre. I am well aware that at this point the Palazzo Nuovo may appear inexplicable in its ugliness, but I would like to suggest a reflection that I will develop further ahead: a significant part of the ugliness of the palazzo, something that even the most benevolent presentations cannot omit, is its utter detachment in relation to its surroundings (which is the character of an artwork, not a building).

\section{RRESPONS IB I LITY}

My fourth interpretation concerns the irresponsibility, not of the architects, but of the clientele. A middle class that was not necessarily very cultivated saw in art an instrument of social ascent and enrichment. At that point, an industrial production of even mediocre and low-quality works was initiated that would fill galleries and museums proliferating through the institution of public spending, in which officials would spend money that was not theirs. I am in no way convinced that their directors would put many of the works that they exhibit in their own houses, let alone buy them if they had to pay out of their own pockets.

The same holds true for architecture, where a previously unthinkable technological omnipotence and an unprecedented standardisation (which we will return to shortly) came across a not-so-ascetic public clientele, that commissioned works such as the headquarters of the Lazio region, though even Fiorito would have made a better choice for a private residence. 


\section{PARERGONALITY}

The fifth interpretation is what I call "parergonality". In the world of works of aura, as we were saying, beauty shifts from the ergon to the parergon. Yet, this parergonalisation has specific repercussions on architecture as, little by little, even the parergon begins to consider itself as an ergon, as an irrelative and absolute work. Architectural antirealism begins when a building is no longer at ground-level, but is placed on an ideal pedestal, no questions asked. This is precisely what must have happened while the Palazzo Nuovo was being designed. It is the phenomenon that Fusco, in his contribution to the catalogue, qualifies as "self-referential": the fact that structures are being built more and more like museums, churches or theatres that are conceived as works in and of themselves, whereby the city as a principle of reality is lost.

The deferral mechanism is implacable: a work of aura (ergon) defers to the container (parergon) the function of aestheticity. But, as I have just said, the parergon in turn becomes the ergon; it conceives of itself as something absolute, released from its environment and from its context. An architectural work does not go as far as the work of aura, in the sense that it does not theorise deliberate aesthetic indifference, if for no other reason but to provide an aesthetically welcoming context for the work of aura; it must embellish it and give it a boost. But in its heart of hearts it already behaves as a work, in the sense that it presents itself as a disaggregated and fluid architecture; a mobile piece, just as a work of art. Only it stays there and does not move. Here, a hyper-aestheticity is generated that generates an anaestheticity or anaesthesia that specifically concerns architecture, and that does not refer to aesthetics as a discipline of beauty but as a discipline of perception, and even of Kant's transcendental aesthetics: that is, of space and time as something that makes our experience of the world possible. When Federica Visconti rightly refers to the fact that the reality that architecture deals with is first and foremost the forma urbis, the spatial context with which it interacts, we are also reminded that we have had a great number of examples of works (I feel it best to define them as such, and among these is undoubtedly the Palazzo Nuovo) in which the surrounding space seemed not to count at all. In the very same way, time did not count, nor did the assumption that, as we will have a chance to see further ahead, is essential for architecture: namely that what is made is destined - whether we like it or not - to last, be it a merit or a memento.

\section{AUTHORIALITY}

My sixth interpretation concerns authorship. There are no longer styles; there are architects. From the parergon promoted to ergon derives an extreme 
individualism: build what you want, without consideration for the context. This is a sort of architectural Stirnerism facilitated by the fact that, initially, twentiethcentury architecture began in the periphery, or in post-war reconstructions, developing a scarce propensity to build in urban centres. Hence the problem of post-wall Berlin, as Fritz Neumeyer recalled last week, where modern architects found themselves having to build in the city centre. I think, however, that someone (and I fear that among them were the architects of the Palazzo Nuovo) must have said to themselves, "Where's the problem?" and did as they pleased. They did as they pleased to the letter, the only constraint being the cost, because when it comes to building opportunities a contemporary architect has huge advantages (actually, disadvantages) compared to his ancestors, and he deals with fewer constraints related to the materials. The authorial Stirnerism becomes Prometheanism, according to which the architect can do what he wishes. And, perhaps dramatically, it supposes (entirely mistakenly) that the residents can do what they wish with themselves; they can be as ductile as the materials.

\section{SUBALTERNITY}

The seventh interpretation has to do with the concept (and the fact) of subalternity as produced by standardisation. In fact, the paradox is that the Prometheanism is only apparent because, with the complicity of the cost constraint, it intertwines - as I briefly recalled earlier - with hyper-standardisation. Thus we have the universal handle; the universal and indestructible plastic chair, from the Cuban shore to that of Algiers; universal anodised windows and doors, from Mexico City to Forcella: namely, all the standards that make building houses possible for everyone and, at the same time, disfigure the environment creating a Benjaminian shock or, if all goes well, banalise it nourishing boredom - "ce monstre délicat", as Baudelaire put it in the opening of Les Fleurs du Mal. It would not take much to conduct a study on the standardised degradation of every single compositional piece, decade after decade: elevators, lights, furniture, windows, handles, switches (which then induces the more perceptible or intransigent ones to heroic remedies, such as the disappearance of switches).

I marvel at the fact that Heidegger, as aware as he was while denouncing Gestell (the imposition of technique) did not take architecture into consideration, which is, by far, where this imposition is felt as most urgent and inescapable. In fact, no architect, not even the most imperious of the archistars, can exempt himself from submitting to the Gestell of a prefabricated building - not even Heidegger (let us not forget that the Hütte in Todtnauberg was a prefabricated building). 


\section{DOCUMENTALITY}

Even in the case of the Hütte, then, we are dealing with a ready-made logic. There is, however, an eighth rule, which I call "documentality". Standardisation is not only imposed by technique, but also by the law. Today Frank Lloyd Wright would never have been able make the helical railing of his structure at the Guggenheim so low; it would have been prohibited by some norm. There is nothing that can be done about this - there is no choice. This is when the emotional moment prevails: crooked, pre-shrivelled, deconstructed buildings. Which means two things.

First, it implies a radically impolitic dimension because architecture, which is attached to the standards of compositional elements by firm and invisible strings, pours out with an absolute individualism and a radical independence from its context. Which is the only freedom that, in the end, it is already granted: freedom for death we might say, with a bit of Heideggerian emphasis. Second, it implies what I call a singular "crisis of the European sciences". I imagine that a traditional architect, dealing with modest variables, traditional materials and consolidated techniques, would know everything about his trade. I also imagine - and, certainly, out of my ignorance I could be greatly mistaken - that a contemporary architect cannot (because it is humanly impossible) dominate more than a minimal portion of the skills necessary in order to build.

This can all be considered within the context of a technological and documental evolution that completely transforms the scenario throughout the course of the professional life of the architect, who, at the age of seventy, finds himself faced with an entirely different technology from that which he studied at university (this is surely what happened to poor Levi-Montalicini). Not to mention the failures caused by globalisation. I am certain that if Isidore of Miletus and Anthemius of Tralles had found themselves building Hagia Sofia in Shanghai, with Pakistani arsenals, they would have thrown in the towel; or they would have fallen back on a less complicated solution, perhaps opting for a "strong signal" and that would have been the end of it.

Faced with such a situation, there would be a very strong temptation on the part of the architect to say that he does something else, and that if he is an architect it is precisely because he does not build - leaving that task to unworthy mechanics, while he continues reading Heidegger and Derrida. I feel a bit more authorised to mention this temptation as it is what occurred in philosophy during the last two centuries, which, feeling as though it had been stepped over by science, sought refuge in a spiteful opposition, claiming that "science 
does not think", that objectivity is bad, thus falling back on magic, like the old Schelling who organised spiritual sessions with the queen of Bavaria. As great as this temptation may be, in both cases it leads nowhere.

\section{PYRAMIDALITY}

I now reach my ninth interpretation, the ninth rule, which I propose to call "Pyramidality": behind every architectural work there sleeps a powerful pyramid, forty centuries of history are prepared, whether we want it or not, and whether we know it or not. At the time when someone believed the Palazzo Nuovo to be beautiful there were many other things that were also thought to be beautiful and that now seem horrible to us: midriff sweaters, maxi coats, bell-bottoms, jackets with large cuffs, teased hair and flower-print blouses. All of those things disappeared a long time ago, Palazzo Nuovo did not. It remains and will remain, a bit less than the Valentino and the pyramids - at least so I hope - but it will remain. It stays even now, when no one considers it beautiful anymore: so much so that it decreases the value of the surrounding real estate (one of my colleagues was being shown an apartment unit in a historic house with a view of Palazzo Nuovo, and the seller, in an attempt to encourage her to purchase it, told her that undisclosed sources assured him that the palazzo would soon be demolished).

Silvia Malcovati, again in the opening remarks of the conference, rightly asserts that architecture must take a stance with regards to reality. In particular - as Capozzi appropriately remembers - it is a three-dimensional structure, a bed, a typical element of furniture and of internal architecture, that Plato refers to in order to define the opposite of art as deceit and mimesis, as imitation of an imitation. Plato states that there are three beds: an ideal one, one made by an artisan, and one drawn by a painter. The last one is devoid of its function as no one can sleep in it or walk around it. Conversely, the artisanal bed is something that preserves certain essential properties of a bed, even if human beings were to disappear. To sum up, if humanity were to disappear art would disappear, the stock market would disappear, Kitsch would disappear, as well as Camp and Pop. But architecture, such as the Mayan temples in Yucatan, would not disappear. It is important for architecture to recognise this essential difference with respect to other human activities; I am certain that it is aware of it, but in certain cases it would seem as though it has forgotten. This is why pyramidality is an inescapable rule in architecture, at least from our longitude, which prevents us from truly learning from Tokyo or from Las Vegas. Where we are from, that which remains is not founded by poets, as Hölderlin wanted, but by architects. 


\section{REALITY}

At last, we have arrived at the tenth and final interpretation, which concerns reality. I would like here to recall an image. Think of the picture of Hitler in March 1945, in the Reichstag (constructed by Speer without the limitations of democracy, something Eisenmann considers to be fatal to architecture), already largely destroyed by the allies. Hitler is looking at the plastic model of the post-war restoration of Linz. There is nothing more antirealistic than this scene, because that model was never going to be actualised - at least not under Hitler's eyes. The model was simply going to remain an idea, a motionless object that perhaps the Russians would have found on the ground, along with the elegant armchairs that Speer had designed for Eva Braun's room in the Bunker.

That was not architecture: it was a three-dimensional watercolour, because Hitler did not deal with limits. Architecture, just as many other human activities, begins with limits, with aesthetic, cultural, material, economic, technical, legislative and social constraints. This is where the true battle is launched. But it is a good battle. As Kant used to say, the dove (symbol of moral initiative) seems to be impeded in its flight by the resistance of the air. Yet, without that resistance, it would not be able to fly.

This is why I believe in the importance of the limits that I have sought to list by speaking of conceptuality, auraticity, supplementarity, irresponsibility, parergonality, authoriality, subalternity, documentality, pyramidality and reality as the sum of all of these limits. They are different limits, and at times antithetical. And I am certain that there are many others that I have ignored because I am ignorant. Clarifying these limits, bringing them into focus in an orderly fashion and confronting oneself with them is, in my judgement, the mark of realism in every field, and, therefore, of realism in architecture as well. 
After the Belgrade Conference this text was improved in two later conferences on Architecture and realism, in Turin and Naples, to which sometimes I refer. Adolf Loos, Parole nel vuoto (Milano: Adelphi, 1992), 253. Bologna: il Mulino, 2006.

Loos, Adolf. Parole nel vuoto. Milano: Adelphi, 1992.

Rosenkranz, Johann. Aesthetik des Hässlichen. Bornträger, 1853.

Sudano, Paolo Mauro. Maestri difficili. Temi d'architettura torinese e il parallelo di una scuola di filosofia. Torino: Rosenberg \& Sellier, 2000. 
JEVREJSKI ZID:

Ajzenmanovo carstvo

\section{Renato Rizzi}

U ovom radu, autor se zalaže da i arhitektura, kao i druge estetske discipline, već dugo ukazije na prvobitni problem: osećaj forme. Forma se smatra mnoštvom ekspresivnih jezika koji potiču od određene vrste znanja. Arhitektura je viđena kao rad realizacije, saznanje znanja, a forma je prezentacija, suština je u osećaju.

Autor tvrdi da je više promenljiv, mada ne jedini među četiri faktora, pravo na znanje. Ako se više ili manje proširi i produbi, veća je ili manja naša sposobnost da klizimo duž osnovne linije. Ili ka "sadržaju istine jednog dela", prema rečima Valtera Benjamina. Pretpostavka, iako tek treba da se dokaže, nameće logiku mišljenja kojoj treba pridružiti estetiku mišljenja: poklon sastavljanja, slika jedinstva celine.

U nekoliko delova, preko teoloških pitanja, scena mišljenja, tumačenja o zastupanju i razmišljanju, ideja, koncepata i fenomena, autor diskutuje o mogućim tumačenjima rada Pitera Ajzenmana.

KLJUČNE REČI: TELOS, IKONOLOGIJA, EPISTEMOLOŠKA PREMISA, FORMA, INTERPRETACIJA, TEOLOGIJA, JEVREJSKA PARADIGMA, GRČKO-HRIŠĆANSKA PARADIGMA

ARHITEKTURA I FILOZOFIJA:

Paradoksi i metamorfoze njihovog sastanka

\section{Chris Younès}

Poznato je da je Žak Derida (Jacques Derrida) istakao ideju suštinskog suživota između filozofije i arhitekture, izjavljujući: „Collège inetrnational de philosophie bi trebalo da obezbedi mesto za sastanke (recontre), sastanak razmišljanja, između filozofije i arhitekture. Ne da bi se konačno sukobljavale, već da se razmišlja o onome što ih je oduvek održavalo zajedno u najsuštinskijem suživotu." Ovaj rad se posebno bavi hipotezom o metamorfozi ovog sastanka da, od jedinstva arhitektonike i principa, postaje mnogostrukost i drugog karaktera. Tako da je tu preispitivanje u smislu granica i prolaza; drugim rečima, u smislu otvaranja. Prvi sastanak se može smatrati kao metaforička igra ogledala u kojoj svako predstavlja sebe kao prevlađujući u odnosu na druge oblike znanja - jedan kao nauke o teoriji, drugi kao nauke o tehnikama. Ovo uređeno i orijentisano poziranje će propasti u isto vreme sa nestankom konačnog kosmosa. U tom raspadu, arhitektura i filozofija su se 
prekomponovale da bi se bavile prostorom i vremenom naseljenih sredina koje utiču ne samo na konstituciju pogleda, već isto tako na transformaciju sveta. Istražuje se kako je njihov interfejs heuristička struktura ispitivanja.

KLJUČNE REČI: FILOZOFIJA, ARHITEKTURA, GRANICE, PROLAZI, METAMORFOZA

\section{MARGINE ARHITEKTURE}

\section{Maurizio Ferraris}

Polazeći od primera naročito ružne Palazzo Nuovo u Torinu, ovaj rad ima za cilj da predstavi, putem poređenja između arhitekture i vizuelnih umetnosti, deset interpretacija (konceptualnost, auralnost, suplementarnost, neodgovornost, pareregonalnost, autorijalnost, podređenost, dokumentalnost, piramidalnost, stvarnost), koje opisuju karakteristike savremene arhitekture kao što i ukazuju na određene granice i pravila sa kojima arhitektura mora da se pomiri.

KLJUČNE REČI: ARHITEKTURA, FILOZOFIJA, VIZUELNE UMETNOSTI,

DOKUMENTALNOST,STVARNOST, DERIDA, ESTETIKA

ZAKON OIKOSA.

Žak Derida i Dekonstrukcija Stanovanja

\section{Francesco Vitale}

Ovaj rad skicira bitne linije rada koji je u toku a koji ima za cilj da prati putanju koju je otviro Derida ka dekonstrukciji stanovanja. Nameravam da pokažem kako je Deridina briga za arhitekturu strogo povezna sa urgentnošću dekonstrukcije stanovanja koja naseljava njegov rad od najmanje Platonove Farmacije (1966), pa nadalje. Prema Deridi, i filozofija i arhitektura su podređene arhaičnoj koncepciji stanovanja koja još uvek opseda naš način razmišljanja i izgradnje mesta stanovanja (teritorija, grad, kuća) i, na taj način, utiče na političku dimenziju našeg života.

KLJUČNE REČI: STANOVANJE, DEKONSTRUKCIJA, KHORA, ONTO-TOPO-POLITIKA, PROSTOR

\section{LA NAVE DI PIETRA/ KAMENI BROD}

\section{Zoran Lazović:}

Svet se stalno gradi i razgrađuje. Da li postoji suštinski paradoks dekonstruktivizma u kreativnim radovima arhitekata? Čemu odgovara arhitektonski projekat? Dnevnik priče u kojoj je pripovedač svoj sopstveni tumač:Od neizvesnog prisećanja i izbledelih kopija do višestrukih novih 
originala. Gde je bio Vavilon arhitekte? Grupni portret. Kriegs Insel in Plannen, Isključenje iz zemaljskog Raja. Blok 24. Kulturni centar Tré́eg Milenijuma. Futuristički pristup Savskom amfiteatru Tré́eg Milenijuma. Urbana Utopija: Omaž gradu Vukovaru. Grad Nade. Cauchemare - košmar. Noćni rad. Imago mundi. Opservatorija budućnosti? Lutanje i život na niskoj frekvenciji. Beogradska Nekroza i Smrt Srbije. Paralela introspekcije, ili smrt mnogih svetova pred nama. Oni koji ne mogu da vide da će umiranje videti neke druge svetove kako nestaju: njihovo propadanje, rastavljanje, nestanak. Pogled u ambis prošlosti: radi nekog traga, ili radi nešto više tragova uporedno. Arhitektura. Slike. Fragmenti. Hibridi. Svedočenje očuvanih slika, objekata, arhitektonskih kompozicija, ikonografskih fragmenata, montaža, sklopova, umetničkih kolaža, mentol brikolaža. Odraz velikih događaja i ideja: neprekidno menjajujući i nestajući Kontekst. Kontekst velikih pokreta. Moda. Trendovi.Glavne tendencije. Ratovi. Kreativni prioriteti i vizije. Lekcija iz anatomije: sučavanje sa sopstvenim projektima i konstruktima, vezivanje, analiza, dekonstrukcija, reminiscencija i rekonstrukcija, se-ćanje (ponovno vraćanje delova celine). Neki trag već uništenog postojanja i neizbežnog nestajanja. Da li postoji iščekivanje i predviđanje događaja i raspadanje, odlazak i povratak? Kakvi su to ramovi imali slike koje su bile nevidljive u to vreme? Pratiti trag kroz Spektar Deride.

KLJUČNE REČI: ARHITEKTURA, IDEJE, KONCEPTI, KONTEKSTI, DEKONSTRUKCIJE, DESTRUKCIJE, RETROSPEKTIVA 